\title{
The Use of TRIPS Flexibilities by Emerging Countries
}

Amélie Robine *

\begin{abstract}
The patent law has been harmonized at the international level in 1994 by the Agreement on TradeRelated Aspects of Intellectual Property Rights (TRIPS). In practice, this text requires all member States of the World Trade Organization (WTO) to recognize the patentability in all industrial sectors. A pharmaceutical patent shall then be granted for any pharmaceutical invention insofar as it fulfills all three criteria for patentability: novelty, inventive step and industrial application. Thus, developing countries can no longer copy molecules protected by patents. At first glance, the TRIPs Agreement completely prevents the development of pharmaceutical industries in the most advanced developing countries from a technological point of view -emerging countries- and dried up sources of supply of cheap medicines for poor countries. However, if the TRIPS agreement strengthens the protection of intellectual property rights, flexibilities have been provided by the wTo law to ease international patent law under certain circums-tances, like public health considerations. The objective of this article is then to show how India, Brazil and Thailand, are using some of these flexibilities to ease the general principle of pharmaceutical inventions patenting according to their development goals, so that other emerging countries can inspire themselves by these examples.
\end{abstract}

\section{RESUMEN}

Las leyes de patente se han armonizado a nivel internacional en 1994 a través del Acuerdo de Propiedad intelectual y Comercio (ADPIC). A través de este acuerdo los países miembros de la Organización Mundial del Comercio (OMC) reconocen el reforzamiento de los derechos de propiedad industrial y en especial, la patentabilidad en todos los sectores industriales. Una patente farmacéutica deberá entonces ser concedida a cualquier invención farmacéutica respectiva en cumpli-

PhD in Law - Associate Researcher at the "Law, Sciences, Techniques" Research Centre of the University of Paris I - Panthéon-Sorbonne - UMR 8103.

1 The TRIPS Agreement is available at: http://www.wto.org/english/docs e/legal e/27-trips.pdf. 
miento a cada uno de los tres criterios para el patentamiento: novedad, altura inventiva, aplicación industrial. Sin embargo, los países en desarrollo no podrán copiar más las moléculas protegidas por patentes. En un primer momento, el ADPIC obstaculiza completamente el desarrollo de las industrias farmacéuticas en la mayoría de los países en desarrollo desde el punto de vista tecnológico y agota las fuentes de abastecimiento de medicinas baratas para los países pobres. No obstante, si los ADPIC fortalecen la protección de los derechos de propiedad intelectual, las flexibilidades provistas por las legislaciones de la Organización Mundial del Comercio para facilitar leyes de de patentes bajo ciertas circunstancias, como las consideraciones de salud pública. El objetivo de este artículo es, entonces mostrar como India, Brasil y Tailandia han utilizado estas flexibilidades para facilitar el principio general del patentamiento de invenciones farmacéuticas de acuerdo a sus metas de desarrollo, de tal forma que otros países emergentes puedan inspirarse en estos ejemplos.

Number of classification: JEL: K33 International Law.

Keywords: TRIPS Agreement -pharmaceutical products- AIDS -patent law- emerging countries.

\section{INTRODUCTION}

The patent law has been harmonized at the international level in 1994 by the Agreement on Trade-Related Aspects of Intellectual Property Rights (TRIPS). ${ }^{1}$ Thus, under Article 27 of this agreement "patents shall be available for any inventions, whether products or processes, in all fields of technology, provided that they are new, involve an inventive step and are capable of industrial application". In practice, this provision requires all member States of the World Trade Organization (WTO) to recognize the patentability in all industrial sectors. The TRIPS Agreement covers then new fields, such as pharmacy or chemistry. A pharmaceutical patent shall be granted for any pharmaceutical invention insofar as it fulfills all three criteria for patentability: novelty, inventive step and industrial application. The recognition of patentability for pharmaceutical inventions is due to the expansion of international trade and correspondingly increased counterfeiting of patented products of multinational firms, however, it places pharmaceuticals on a legal equal footing with other industrial products, despite the fact that drugs, as they relate to public health, are not like other goods. Previously, countries were free or not to adhere to international conventions on intellectual property (Paris Convention for the protection of industrial property of March $20^{\text {th }}, 1883$, for example). Two systems existed then: industrialized countries had put in place intellectual property systems 
to protect their innovations, and developing countries traditionally excluding medicines from patent protection, which allowed them in practice to copy, in any lawful point of view of their legal system, the molecules patented in industrialized countries provided that these "tolerated" copies were not re-exported to protected markets (Robine, 2008).

The TRIPS Agreement came into force on January $1^{\text {st }}, 1995$, but provided transition periods for countries according to their level of development. Thus, industrialized countries had until January $1^{\text {st }}, 1996$ to adapt their legislation on intellectual property standards of the TRIPS Agreement, developing countries which excluded pharmaceuticals from patent protection and the Least Developed Countries (LDCs) had, however, until January $1^{\text {st }}, 2005$ to comply with internationals standards ${ }^{2}$, this period has been postponed to January $1^{\text {st }}, 2016$ for LDCs. ${ }^{3}$ The construction of drug industries in emerging countries has therefore been based on strategies to copy molecules patented in industrialized countries, as was formerly the case in tha same industrialized countries.

Therefore, since 2005, developing countries can no longer copy molecules protected by patents, the practice of "legal copying" (Remiche, 2002) has become incompatible with the provisions of the agreement. They must therefore wait for the patent expiry of innovative molecules, twenty years, ${ }^{4}$ to have the right to make legal copies. The TRIPS Agreement then prevents the development of pharmaceutical industries in the most advanced developing countries from a technological point of view -emerging countries- and dried up sources of supply of cheap medicines for poor countries (Adelman et al., 2005; wHo, 2006). Only the least developed countries are allowed to continue to make "tolerated" copies of patented drugs, but they do not usually have production capacity in the pharmaceutical sector. At first glance, therefore, the only authorized copies are limited to those who lack the technical means to manufacture them: the LDCS.

However, if the TRIPS agreement strengthens the protection of intellectual property rights (Watal, 2001), flexibilities have been provided by the wTO law. A whole series of provisions contained in the TRIPS Agreement allows Member

Articles 65 and 66 of the TRIPS Agreement.

Decision of the Council for TRIPS of June $27^{\text {th }} 2002$ (doc $n^{\circ} \mathrm{IP} / \mathrm{C} / 25$ ).

4 Article 33 of the TRIPS Agreement. 
States to ease international patent law under certain circumstances. And, under pressure from international public opinion, backups of the TRIPS Agreement have been repeated in a separate text: the Doha Declaration of November $14^{\text {th }}, 2001$, to ensure a balance between protecting innovation and public health, and wider access to medicines in poor countries. ${ }^{5}$

The objective of this article is then to show that even if international patent law drastically limits the local production of medicines in emerging countries, it contains however a number of general and special flexibilities, from which emerging countries can take advantage to locally manufacture pharmaceutical products at low prices (Correa, 1996). We will show how India, Brazil and Thailand, are using some of these flexibilities to ease the general principle of pharmaceutical inventions patenting, according to their development goals, so that other emerging countries can inspire themselves by these examples.

We will analyse, in a first moment, how emerging countries take advantage of general backups of the TRIPS Agreement, i. e., flexibilities left to Member States in the implementation of the text (I), before submitting in a second time how emerging countries are using the special flexibilities of the agreement, namely the exceptions, to the exclusive rights of the patentee provided to protect public health (II).

\section{UTILIZATION BY EMERGING COUNTRIES OF THE GENERAL FLEXIBILITIES CONTAINED IN THE TRIPS AGREEMENT}

To win the support of the majority of the wTO Member States, the TRIPS Agreement was draft in general terms. It therefore gives a real degree of freedom to these countries regarding its application. More specifically, some emerging countries have benefited from inaccuracies in the text, and in particular from the lack of definition of the patentability criteria, in order to adapt their patent system to the specific objectives of their socio-economic and technological policy (Remiche et Desterbecq, 1996). Such is the case of Brazil and India which adopted restrictive patentability criteria to limit the scope of pharmaceutical inventions patents. In doing so, these countries have introduced diverse legal devices, which shows that various alternatives are possible. Brazil established an original mechanism of control for pharmaceutical patents exercised by the drug agency, named "anuên-

\footnotetext{
The Doha Declaration is available at:

http://www.wto.org/english/thewto e/minist e/min01 e/mindecl e.htm.
} 
cia prévia" while India has chosen to specifically exclude me-too drugs from patentability.

\section{The Brazilian mechanism of prior authorization}

Brazil established a new mechanism for granting pharmaceutical patents: the delivery of these patents is indeed subject to the prior authorization of ANVISA, the Brazilian drug agency. ${ }^{6}$ To justify this special control, Brazil refers to the lack of technical expertise of the National Institute of Industrial Property (NIIP) in the pharmaceutical sector, because it was not conceivable to submit the granting of patents in an, sensitive area, as it relates to public health, to a body found incompetent. Under the Industrial Property Act, ${ }^{7}$ as amended by a Provisional Measure of December $14^{\text {th }} 1999,{ }^{8}$ followed by a Law of February $14^{\text {th }} 2001,{ }^{9}$ revision of applications for pharmaceutical patents is then given not only to NIIP, but also to the body which also authorizes the marketing of medicines (Basso, 2004).

The ANVISA prior authorization is therefore an additional stage in the process of reviewing the patent application. By adopting a sui generis mechanism in analysing patent applications for pharmaceutical products and processes, Brazil clearly shows its willingness to take into account public health issues in patent law, since lack of prior authorization of ANVISA, no pharmaceutical patent can be granted (Beas Rodrigues, 2005). Specifically, since December $14^{\text {th }} 1999$ (2003, actually), patent applications relating to pharmaceutical products or processes are subject to the review of NIIP, and then of ANVISA. The NIIP is responsible for the classic analysis of the patentability criteria (novelty, inventive step, industrial application), while ANVISA review these same criteria following the requirements of national public health. In practice, the agency adopted a criterion of absolute novelty that allows it to exclude second therapeutic indications, me-too drugs, etc. from patentability.

This legal mechanism, although controversial (De Freitas, 2004; Instituto Dannemann Siemsen de Estudos de Propriedade Intellectual, 2005; Barbosa,

\footnotetext{
6 Article 229-C of Patent Act of 1996 says: "A concessão de patentes para produtos e processos farmacêuticos dependerá da prévia anuência da Agência Nacional de Vigilância Sanitária (ANvisA)".

7 Law n 2.979 of May $14^{\text {th }} 1996$, published to DOU of 05/15/1996.

8 Provisional Measure $n^{\circ} 2.006$, published to DOU of 12/15/1999.

9 Law ${ }^{\circ} 10.196$, published to DOU of 02/16/2001.
} 
2006), was legitimized by a ruling of the $38^{\text {th }}$ Federal Chamber of Rio de Janeiro. ${ }^{10}$ The Court based its decision on Article XXIX of the Federal Constitution of 1988 to remind on the one hand that intellectual property rights may be issued in Brazil only insofar as they respect social, economic and technological country's interests and to devote, on the other hand, the legitimacy of control exercised by the drug agency. Since it helps to ensure that pharmaceutical patent applications meet the patentability criteria and the public health objectives of the country, the prior authorization of ANVISA falls within the scope of Article XXIX of the Constitution. It is therefore legitimate.

So, Brazil has put into place a singular legal mechanism limiting the patentability of pharmaceuticals, and thus enabling the country to locally produce, when the prior permission of ANVISA is refused, medicines at low prices. In the same way, but in a different manner, however, India has adopted restrictive patentability criteria in its industrial property law.

\section{Indian exclusion of me-too drugs}

The patentability criteria set out in Article 27 of the TRIPS Agreement (novelty, inventive step, industrial application) are not defined by the text. Thus, like Brazil, India has played on the flexibility of this provision to adopt restrictive criteria of novelty and inventive activity, limiting the patentability of pharmaceutical inventions exclusively to drugs that are really new and innovative. Section $3 \mathrm{~d}$, introduced in Indian legislation by the Patent Act of 2005, specifically excludes the patentability of new forms, properties and uses of known substances and processes. And it specifies that the salts, esters, ethers, polymorphs, metabolites, pure form, particle size, isomers, mixtures of isomers, complexes, combinations and other derivatives of known substances shall be considered to be the same substance, unless they differ significantly in properties according to efficacy. This clause, therefore, opposes the phenomenon of evergreening of patents (i.e., the fact to apply for patents for minor changes), which could lead to infinite protection of princeps medicines.

Restricting significantly the scope of patentability in the pharmaceutical field, this provision is now the subject of extensive debate on the international scene. This is shown by the lawsuit brought by Novartis following the refusal of Indian Justice to grant a patent for its blockbuster medicine against cancer, Gleevec

${ }_{10}$ Case $^{\circ}{ }^{2}$ 2004.51.01.513854-1 of September $5^{\text {th }} 2005$. 
(Mamou, 2007; Mueller 2007; Bradol, 2007). Patented in the USA and in Europe in 1993, Novartis filed in 1998 a patent application in India. In response, the Swiss laboratory was granted exclusive rights to market the product for five years. Indian firms had then to cease to produce and export copies of Gleevec. In 2005, the Indian patent office reviewed the application filed in 1998 by Novartis. On January $25^{\text {th }} 2006$, it rejected the application for a patent on the drug, considering that the product was not new within the meaning of section $3 \mathrm{~d}$ of Indian patent Law, the company having not provided the proof of the greater effectiveness of the new Gleevec. ${ }^{11}$ Novartis argues, however, that its patent application covers a molecule with a higher bioavailability of $30 \%$. It would therefore be more effective. This gain of bioavailability and hence of potential effectiveness justify a patent application, because it is indeed an innovation entering within the framework of incremental innovations. In May 2006, Novartis reacts to the negative opinion of the Indian patent office by bringing two lawsuits: one to challenge the decision of the Indian patent office, the second to challenge the constitutionality of section $3 \mathrm{~d}$ of Indian patent Law. In August 2007, the High Court of Chennai declared itself incompetent to judge the constitutionality of the provision at issue, i.e., its compliance with wTO rules. This decision enables India to keep its law limiting the scope of patents. It also highlights the divergent interests of industrialized countries inventors of medicines and poor countries who need patented medicines and copy them. Novartis announced not to appeal this decision (Cuzin, 2007). However, the Swiss group declared renounce to invest in research and development in India to the advantage of other emerging countries, like China.

The TRIPS Agreement confers therefore, through certain provisions of general nature, a real freedom to Member States to implement their obligations in terms of industrial property. In addition to these general flexibilities, special safeguards have been considered to take account of public health requirements, as compulsory licensing. Brazil and Thailand have recently issued such licences to safeguard their public programs of access medicines.

$11 C f$. V. RENGASAMY, Asst. Controller of Patents and Designs, Decision re: Novartis AG, Switzerland, The Applicant; Natco Pharma Ltd, India, The Opponent: "I do not agree with the contention of the Applicant that this application claims a new substance. It is a new form of a known substance. It is found that this patent application claims only a new form of a known substance without having any significant improvement in efficacy. (...). Hence I conclude that the subject matter of this application is not patentable under section $3 \mathrm{~d}$ ) of the Patent Act, 1970 as amended by the Patents (Amendment) Act, 2005”. 
IMPLEMENTATION BY EMERGING COUNTRIES OF EXCEPTIONS TO PATENTEE RightS IN ORDER TO Protect Public Health

Compulsory license is a classic flexibility case of patent law, under which a third party may be given, in certain cases and under certain conditions, the right to exploit a patented invention, and ignoring the will of the patentee. Authorized by Article 31 of the TRIPS Agreement under the heading "Other Use without Authorization of the Right Holder", compulsory licenses are part of the overall attempt of the agreement to strike a balance between protection of inventions and access to innovations. ${ }^{12}$ Article 31 leaves member States free to determine the grounds upon which a compulsory license can be granted, while organizing two authority licenses regimes (Kahn, 2007): a general one which requires a prior voluntary license request on reasonable commercial terms and conditions (in the case of lack or insufficiency of explotation of the invention), and a special regime which applies in the case of national emergency or any other circumstance of extreme urgency or, in case of public non-commercial use and practices deemed anticompetitive, requires no prior request of voluntary license. This special regime applies to license in the public interest or in the interest of public health. But whatever the regime, the compulsory license must be non-exclusive, time-limited, non-assignable, authorized "predominantly for the supply of the domestic market of the member authorizing such use", and give rise to adequate remuneration of the patentee.

The WTO member States have insisted on the legitimacy of countries using the mechanism of the compulsory license for public health reasons in the Doha Declaration of November $14^{\text {th }} 2001$ on TRIPS and Public Health. This political declaration marked a turning point for the international patent law, insofar as it needs to take into account health requirements. And emerging countries have played on the political strength of the text to take necessary measures for public health. Thus, Brazil has in a first time threatened the multinational pharmaceutical companies to issue compulsory licenses to negotiate the prices of their patented anti-retrovirals (A) and that Thailand, followed by Brazil, have issued compulsory licenses to import and then manufacture copies of patented drugs considered too expensive for their public programs of access to medicines (B).

12 Article 7 of the TRIPS Agreement. 
The use of the threat of compulsory licensing by Brazil

In accordance with Section III of the Industrial Property Act of 1996, a compulsory license can be issued in Brazil in cases of abuse of the right of the patentee, abuse of economic power, lack of exploitation of invention on the national territory, inadequate marketing of the patented product (or a product which do not meet the needs of the market), and for patent dependency, in case of national emergency or public interest. A license can be required only after a period of three years from the granting of the patent, except in cases of national emergency, public interest or patent dependency.

Based on the recognition of the primacy of public health over economic interests, Brazil has used the mechanism of compulsory licensing in a unique and strategic way. He threatened the Big Pharma (Merck, Roche, Abbott) on several occasions $(2001,2003,2005)$ to issue compulsory licenses to obtain significant reductions in the prices of patented anti-retrovirals (Efavirenz, Indinavir, Nelfinavir, Lopinavir/Ritonavir). Relying on the technical capacities of the public laboratory, Far-Manguinhos, to reproduce the drugs in question at very competitive costs, the government puts forward the fact that prices of patented molecules could not only limit the number of patients taken in charge by the program of fight against AIDs, but also to compromise in the long run its sustainability (Bermudez et al., 2004). This strategy has proved very interesting, since then the country has obtained price reductions ranging from $40 \%$ to $65 \%$ (Ford et al., 2007).

After having, in a first time, used the threat of compulsory licensing as a strategic instrument in the problem of access to medicines, emerging countries have, in a second time, reinforced by international public opinion, implemented this classic flexibility of patent law.

Granting of compulsory licensing in Thailand and Brazil

In Thailand, the compulsory licensing mechanism has been organized in Part $\mathrm{v}$ of the Patent Act of 1999. The Thai regime of compulsory licensing is similar to the Brazilian one: a compulsory license can be requested from the expiration of three years from the granting of a patent if the protected invention is not locally produced, when the production does not meet national needs or has unreasonably high prices, other reasons are patent dependency, national consumption use (as supply of medicines), and national defence or security. 
Thailand, and then Brazil, recently took the risk of using this flexibility permitted by wTO Law in order to promote access to medicines considered vital for their populations. In 2006, Thailand issued a compulsory license for public interest for Merck's Efavirenz to ensure the sustainability of its programme of public access to drugs against AIDs. In 2007, it issued two other authority licenses: one for Sanofi-Aventis' Plavix, which is used in the treatment of cardiovascular disease, and one for Abbott's Kaletra. ${ }^{13}$ And in 2008, it announced the granting of compulsory licenses for three anti-cancer drugs (Shashikant, 2008). Brazil issued a compulsory license for public interest for Merck's Efavirenz in May 2007, ${ }^{14}$ the aim being to ensure the financial viability of universal and free access to drugs against AIDS. In the case of both Thai and Brazilian licences, they are issued for a limited period of time (five or seven years, depending on the licenses), royalties are scheduled for patent holders and copies of patented medicines will be first imported from India and then produced by national public laboratories (The Government Pharmaceutical Organization for Thailand, Far-Manguinhos for Brazil).

These licenses were, however, not granted without difficulties. The countries are subject to threats of trade reprisals (Cawthorne and Dayal, 2006). Thus, Abbott decided to withdraw seven new drugs from the Thai market (Deron, 2007) and the USA placed Thailand on the blacklist of counterfeiting countries (USTR, 2007), which means it faces trade sanctions. Merck considers, that the Brazilian decision could discourage foreign investment, while acknowledging that the decision is in line with international agreements on patents, since the wTO meeting in Doha (Merck, 2007). Can we see in this reaction the beginning of an integration of new issues of public health requirements imposed on patent holders? In any case, the licenses issued by Brazil and Thailand led Abbott to reduce the price of Kaletra (Lopinavir / Ritonavir) and Aluvia (new version of Kaletra that does not require refrigeration) in over forty developing countries (Abbott, 2007).

13 "Decree of Department of Disease Control, Ministry of Public Health, regarding Exploitation of Patent on Drugs \& Medical Supplies by the Government on Combination Drug between Lopinavir \& Ritonavir”, available at: http://www.cptech.org/ip/health/c/thailand/thai-cl-kaletra en.pdf [consulted 11/06/2007].

14 Decree $n^{\circ} 6.108$ of May $4^{\text {th }} 2007$, published to DOU of May $7^{\text {th }} 2007$. 


\section{CONCLUSION}

The TRIPS Agreement, which came into force on January $1^{\text {st }}, 1995$, has strengthened protection of intellectual property rights at the international level. Indeed, now all wTO Member States, with the exception of least developed countries, must recognize the patentability of pharmaceutical inventions for twenty years. Accordingly, emerging countries must wait until the expiration of patents for innovative molecules to make copies. However, general and special safeguards have been included within the agreement to meet the requirements of general interest and public health. And some emerging countries, like Brazil, India and Thailand have taken advantage of these flexibilities in order to limit the patentability of pharmaceuticals and to produce copies at low prices. Thus, Brazil has introduced a new mechanism in the issuing of pharmaceutical patents, India has established patentability criteria extremely tight, preventing the patentability of any invention which is not totally new and inventive, and Brazil and Thailand have used the mechanism of compulsory licensing to get price reductions on certain patented molecules or to get the right to import and manufacture cheap copies of innovative medicines. While it is true that emerging countries face, however, the multinational companies or developed countries when implementing the flexibilities offered by the international patent law, we have to encourage other emerging countries to use provided legal mechanisms to promote access to medicines, so that the right to health is respected in all countries.

\section{REFERENCES}

Abbott. 2007. "Abbott Agrees with World Health Organization Director-General to Expand Access to Kaletra/Aluvia (Lopinavir/Ritonavir)." April 10 ${ }^{\text {th }}$ 2007. Available at: http://www.abbott.com/global/url/pressRelease/en_ US/60.5:5/Press_Release_0442.htm [consulted 11/08/2007].

Adelman C., Norris J., Weicher J. 2005. "Access to Medicine - The Full Cost of HIV/AIDS Treatment." Hudson Institute Review White Paper: 1-24.

Basso M. 2004. "A Anvisa e a Concessão de Patentes Farmacêuticas." October 18 ${ }^{\text {th }}$ 2004. Available at: http://www.tecpar.br/appi/News/A\%20Anvisa\%2 0e\%20a\%20concess\%E3o\%20de\%20patentes\%20farmac\%EAuticas.pdf [consulted 10/23/2007]. 
Barbosa D. B. 2004. "A Inconstitucionalidade da Anuência da ANVISA no Procedimento de Concessão de Patentes como Manifestação Discricionaria da Administração Federal.” July 2004. Available at: http://denisbarbosa.addr. com/anuencia.doc [consulted 10/20/2006].

Beas Rodrigues E. 2005. "Anuência Prévia: Integração do Direito à Saude aos Direitos de Propriedade Intelectual." Revista dos Tribunais 840: 84-106.

Bermudez J., Auxilidora Oliveira M. and Costa Chavez G. 2004. “O Acordo TRIPS da OMC e os Desafios para a Saude Publica." In Bermudez J., Auxiliadora Oliveira M. and Esther A. (dir.), Acesso a Medicamentos: Derecho Fundamental. Papel del Estado. Rio de Janeiro: Fiocruz/ENSP.

Bradol J.-H. 2007 March 1st. "Novartis affronte le Parlement indien." Le Monde, p. 23.

Cawthorne P. and Dayal A. 2006. "Thailand Still Shows the Way on HIV/ AIDS." The Nation, December $2^{\text {nd }}$ 2006. Available at: http://www. nationmultimedia.com/2006/12/02/opinion/opinion 30020541.php [consulted July 20th 2008].

Correa C. 1996. "Développements récents dans le domaine des brevets pharmaceutiques: mise en œuvre de l'accord sur les ADPIC." RIDE 1: 23-35.

Cuzin E. 2007. "Médicaments et brevets: le Sud se rebiffe." Pharmaceutiques (no Review Number): 78-79.

De Freitas L. M. 2004. “Bis in Idem.” June 29th 2004. Available at: http://noticias. aol.com.br/negocios/industria/2004/06/0009.adp [consulted 10/07/2005].

Deron F. 2007 January $3^{\text {rd }}$. "La Thaïlande autorise des génériques de médicaments protégés par des brevets." Le Monde, p. 26.

Ford N., Wilson D., Costa Chaves G., Lotrowska M. and Kijtiwathakul K. 2007. "Sustaining Access to Antiretroviral Therapy in the Less-Developed World: Lessons from Brazil and Thailand." AIDS 21: 21-29.

Instituto Dannemann Siemsen de Estudos de Propriedade Intelectual. 2005. Comentarios à Lei da Propriedade Industrial. Rio de Janeiro: Renovar.

Kahn A.-E. 2007. "Les licences obligatoires.” In Moine-Dupuis I. (dir.) Le médicament et la personne - Aspects de droit International, pp. 219-243. Paris: Litec.

Mamou Y. 2007, January 24 ${ }^{\text {th }}$."Les ONG en guerre contre le laboratoire Novartis." Le Monde, p. 13.

Merck. 2007. "Merck \& Co., Inc. Statement on Brazilian Government's Decision to Issue Compulsory License for Stocrin." May $4^{\text {th }} 2007$. Available at: http://www.merck.com/newsroom/press_releases/corporate/2007_0504. html [consulted 05/05/2007]. 
Mueller J. 2007. "Novartis, Patent Law, and Access to Medicines." The New England Journal of Medicine 6: 541-543.

Remiche B. 2002. "Révolution technologique, mondialisation et droit des brevets." RIDE 1: 83-124.

Remiche B. and Desterbecq H. 1996. "Les brevets pharmaceutiques dans les accords du GATT : l'enjeu ?.” RIDE 1: 7-68.

Robine A. 2008. Transfert et acquisition de la technologie dans les pays émergents - L'exemple brésilien de l'accès aux médicaments contre le SIDA. $\mathrm{PhD}$ Thesis, University of Paris I - Panthéon. Sorbonne.

Shashikant S. 2008, April 1 $1^{\text {st }}$ "Recent Thai Compulsory Licenses and the Aftermath." Available at:

http://www.twnside.org.sg/title2/health.info/2008/twnhealthinfo20080402.htm [consulted July 20th 2008].

USTR. 2007. "Thailand on Priority Watch List because of Use of TRIPS Flexibilities." May $3^{\text {rd }}$ 2007. Available at: http://www.ustr.gov/ [consulted 04/05/2007]. “Thaïlande: sur la liste noire." October $29^{\text {th }}$ 2007. Available at: http://www.sidanet.asso.fr/webapps/komplete/index.php?KTURL=mod_ quotimed.html\&page $=70$ [consulted 10/30/2007].

Watal J. 2001. Intellectual property rights in the WTO and developing countries. La Hague: Kluwer Law International.

WHO. 2006. "Access to Aids medicines stumbles on trade rules." In wHO Bulletin, 84 (May): 342-348. 



\title{
Colaboradores
}

\section{Abigail Rodríguez}

\begin{abstract}
Abigail Rodríguez Nava es doctora en Ciencias Económicas por la Universidad Autónoma Metropolitana y candidata a doctora en Ciencias Financieras por el Instituto Tecnológico y de Estudios Superiores de IMonterrey. Realizó estudios de Maestría en Economía con especialidad en Política Económica en la Universidad Nacional Autónoma de México. Ha laborado en la Secretaría de Educación Pública y como docente en el Tecnológico de Monterrey (ITESM). Actualmente es profesora titular de tiempo completo de la Universidad Autónoma Metropolitana-Unidad Xochimilco y miembro del Sistema Nacional de Investigadores SNIConacyt. Entre los reconocimientos recibidos se encuentra el Premio a la Mejor Tesis de Doctorado en Ciencias Sociales 2005, otorgado por la Academia Mexicana de Ciencias.
\end{abstract}

\section{Francisco Venegas}

Francisco Venegas Martínez es doctor en Matemáticas por la Universidad Nacional Autónoma de México (UNAM) y doctor en Economía egresado de Washington State University. Realizó su posdoctorado en Finanzas por la Oxford University. Tiene estudios de maestría en Investigación de Operaciones en la UNAM, maestría en Matemáticas en la unAm y de maestría en Economía en el Instituto Tecnológico Autónomo de México. Ha sido docente en prestigiadas instituciones de México y del extranjero entre las cuales destaca la UnAm, la UAm-I, el CIDE, El Colegio de México, la Universidad Anáhuac (UA), el Colegio de la Frontera Norte (COLEF), la Universidad Panamericana (UP), Washington State University (wsu) y en Oxford University. Tiene experiencia en el sector público, como asesor del Tesorero del Gobierno del Distrito Federal y del subsecretario de Desarrollo y Programas Energéticos de la Secretaría de Energía (SENER). En el sector privado ha sido Director de Análisis e Investigación del MexDer, Mercado Mexicano de Derivados, S. A. de C. V. Actualmente es profesor-investigador en la Escuela Superior de Economía del Instituto Politécnico Nacional. Es miembro del Sistema Nacional 
de Investigadores SNI-Conacyt (Nivel III), miembro de la Academia Mexicana de Ciencias y miembro de varios Consejos de Administración y Comités de Riesgos de instituciones financieras nacionales. Entre los reconocimientos recibidos se encuentran el Premio de Investigación del Mercado Mexicano de Derivados MEXDER (en dos ocasiones), y el Premio en Investigación Económica Mtro. Jesús Silva Herzog, edición 2003, otorgado por el Instituto de Investigaciones Económicas de la UNAM.

\section{Enrique Hernández Laos}

Profesor-investigador de tiempo completo del Departamento de Economía de la Universidad Autónoma Metropolitana, Unidad Iztapalapa. Miembro de la Comisión del Doctorado en Estudios Sociales, Línea de Economía Social, de la misma universidad. El doctor Hernández Laos es egresado del Instituto Tecnológico y de Estudios Superiores de Monterrey, en donde cursó la licenciatura en Economía y egresó en 1967. Es, además, egresado del Centro de Estudios Económicos y Demográficos de El Colegio de México, en donde cursó la Maestría en Economía y egresó en 1969. En 1978 egresó, con el grado de Doctor en Economía, de la Escuela de Estudios Sociales de la Universidad de East Anglia. Ha sido profesor y visiting schoolar de diversas universidades, entre las que destaca el Centro de Estudios Latinoamericanos de la Universidad de Stanford. El profesor Hernández Laos es autor de más de 60 artículos científicos sujetos a arbitraje, y es autor también de más de 30 libros especializados, en los campos del desarrollo económico y la productividad, el desarrollo regional, la cuantificación de la pobreza y la distribución del ingreso en México y en América Latina. Actualmente trabaja en la elaboración de un extenso trabajo sobre el crecimiento económico y la productividad en México en el Siglo XX.

\section{Sonia Beatriz, Roitter}

Sonia Roitter es doctorante en Economía en la Facultad de Ciencias Económicas, Universidad Nacional de Córdoba (F.C.E.-U.N.C.) y Licenciada en Economía por la misma Universidad. Sus áreas de investigación son: economía laboral, competitividad, PYMES, cambio tecnológico, procesos de aprendizaje en las empresas. Se ha desempeñado como docente en el posgrado de la Universidad Nacional de General Sarmiento y como consultora en diversoso proyectos del BID, FUNDES y CEPAL, entre otros. Actualmente se desempeña como Coordinadora de Formación del Instituto 
de Industria en la Universidad Nacional de General Sarmiento, desde Julio 2006. Coordinadora de la Carrera de Economía Industrial, Instituto de Industria, Universidad Nacional de General Sarmiento, desde noviembre 2003 y como Investigadora Docente Adjunta (categoría C, por concurso) en el Instituto de Industria, Universidad Nacional de General Sarmiento, desde marzo de 2005.

\section{Analía Erbes}

Analía Erbes es doctorante de Ciencias Sociales en la Universidad Nacional de Buenos Aires. Realiza estudios de maestría en Gestión de la Ciencia, la Tecnología y la Innovación en la Universidad Nacional de General Sarmiento-Centro REDESIDES. Es licenciada en Economía Industrial por la Universidad Nacional de General Sarmiento-Buenos Aires-Argentina. Sus áreas de investigación son: economía laboral, competitividad, PYMES, cambio tecnológico, procesos de aprendizaje en las empresas. Ha participado en diversos proyectos de investigación, docencia y en actividades de consultoría en la secretaría de ciencia, tecnología e innovación productiva (actualmente Ministerio de Ciencia, Tecnología e Innovación Productiva), OIT, FUNDES y BID. Actualmente se desempeña como investigadora docente asistente de primera (categoría D1, interina) en el Instituto de Industria, Universidad Nacional de General Sarmiento, desde febrero de 2003.

\section{Gabriel Yoguel}

Economista, investigador-docente, profesor titular del Instituto de Industria de la Universidad Nacional de General Sarmiento. Actualmente coordina el proyecto Generación, circulación y apropiación de conocimiento en tramas productivas argentinas, que es parte del programa sobre la economía del conocimiento coordinado por IDRC-FLACSO México. A su vez, coordina la sección argentina del proyecto sobre la economía del conocimiento Eulaks. Ha dirigido múltiples proyectos sobre esas temáticas financiados por el Ministerio de Ciencia y tecnología y otras instituciones. Es evaluador de proyectos del CONICET y del Ministerio de Ciencia y Tecnología. Es autor de más de treinta artículos en revistas internacionales y nacionales, ha participado como editor en quince libros y como autor en más de treinta capítulos de libros editados en Argentina y en el exterior. Es referee de las revistas Desarrollo Económico, Redes, Revista de la Cepal, Innovation: Management, Policy \& Practice y Economy Innovation and New technologies, entre otras. Sus competencias y áreas de interés se centran en sistemas complejos 
tramas productivas y generación y apropiación de conocimiento. Ha realizado diversos trabajos de consultoría para diversos organismos internacionales tales como CEPAL, BID, Banco Mundial y OIT.

\section{Marcelo F. Delfini}

Marcelo Delfini es doctorante de Ciencias Sociales en la Universidad Nacional de Buenos Aires y licenciado en Sociología por la Universidad de Buenos Aires (UBA) Ha participado en diversos proyectos de investigación y docencia. Actualmente se desempeña como docente en la carrera de Relaciones del Trabajo en la Facultad de Ciencias Sociales en la Universidad de Buenos Aires y como docente e investigador en la Universidad Nacional de General Sarmiento, es Miembro del Comité de Publicaciones de la UNGS.

\section{Andrea Pujol}

Andrea Pujol es profesora titular de la cátedra de Psicología laboral e investigadora de la Facultad de Psicología de la Universidad Nacional de Córdoba. Actualmente, se desempeña como coordinadora académica de la Especialización en Psicología del Trabajo y las Organizaciones de la Facultad de Psicología y como docente de posgrado en la maestría en Desarrollo Económico de la UNGS y en la maestría en Ciencias de la Ingeniería de la Facultad de Ciencias Exactas de la UNC, en temáticas vinculadas a la gestión de procesos de innovación en empresas y redes. En el ámbito profesional, cuenta con experiencia de más de quince años en consultoría y capacitación. Se especializa en la gestión de los saberes y el compromiso del personal en los procesos de innovación tecnológica y organizativa, ha realizado servicios de asistencia técnica internacional y ha acompañado numerosos procesos de desarrollo organizacional en organizaciones públicas, privadas y de tercer sector.

\section{Amélie Robine}

Amélie Robine es doctora de Leyes por la Universidad de París I- Panthéon-Sorbonne y maestra de Leyes en desarrollo y finanzas por el Instituto de Paz y Legislación de Desarrollo. Sus áreas de especialidad son: negocios internacionales, propiedad intelectual, transferencia de tecnología, leyes farmacéuticas y legislación del medio ambiente. 
Ha sido investigador visitante en el Indian Council Social Sciences Research, en la Universidad Central de Brasil y en la Universidad Federal de Río de Janeiro. Actualmente se desempeña como Investigadora Asociada en el Centro Nacional de Investigación Científica de "Leyes, Ciencias y Técnicas" (UMR 8103) en la Universidad de París I- Panthéon-Sorbonne. 